\title{
Age- and cell-related gene expression of aromatase and estrogen receptors in the rat testis
}

\author{
C Bois ${ }^{1,2}$, C Delalande ${ }^{1,2}, M_{\text {Nurmio }}^{3}$, M Parvinen $^{3}$, L Zanatta $^{1,2,4}$, J Toppari $^{3}$ \\ and S Carreau ${ }^{1,2}$ \\ ${ }^{1}$ Laboratoire Estrogènes et Reproduction, EA 2608, Université de Caen Basse Normandie, Esplanade de la Paix, F-14032 Caen Cedex, France \\ ${ }^{2}$ INRA USC 2006, F-14032 Caen Cedex, France \\ ${ }^{3}$ Departments of Physiology and Pediatrics, University of Turku, 20520 Turku, Finland \\ ${ }^{4}$ Departamento de Bioquímica, Centro de Ciências Biológicas, Universidade Federal de Santa Catarina, Bairro Trindade, Cx, Postal 5069, \\ CEP 88040-970 Florianópolis, SC, Brazil \\ (Correspondence should be addressed to S Carreau; Email: serge.carreau@unicaen.fr)
}

\begin{abstract}
Spermatogenesis is a complex and coordinated process leading to the formation of spermatozoa. This event, which is under the control of numerous endocrine and paracrine factors, seems to also be controlled by estrogens which exert their effects via nuclear estrogen receptors (ESRs) ESR1 and ESR2. Estrogens are synthesized by aromatase which is biologically expressed in the rat testis. The objective of our study was to clarify the gene expression patterns of aromatase and ESRs according to age and in the two compartments of the adult rat testis. In the adult, transcripts of aromatase vary according to the germ cell type and to the stages of seminiferous epithelium, a maximum being observed at stage $\mathrm{I}$. The ESR1 gene is highly expressed in the adult testis and in stages from VIlc-d to XIV. Moreover, both ESR mRNA levels are higher in purified round spermatids than in pachytene spermatocytes, suggesting a putative role of estrogens in the haploid steps of spermatogenesis. The variability of the results in the expression of both ESRs led us to explore the putative presence of variants in the rat testis. Concerning ESR1, we have shown the presence of the full-length form and of one isoform with exon 4 deleted. For ESR2, besides the wild type, three isoforms were observed: one with exon 3 deleted, another with an insertion of 54 nucleotides, and the last one with both modifications. Therefore, the stage-regulated expression of aromatase and ESR1 genes in the rat testis suggests a likely role of estrogens in spermatogenesis.
\end{abstract}

Journal of Molecular Endocrinology (2010) 45, 147-159

\section{Introduction}

The seminiferous epithelium supports the spermatogenesis which is a complex process leading to the formation of spermatozoa from spermatogonia. Tubules are composed by specific associations of germ cells and Sertoli cells, which progress synchronously through the stages of seminiferous epithelium. In rat, 14 stages (I-XIV) have been described (Leblond \& Clermont 1952, Parvinen 1982, Wing \& Christensen 1982). During their progression, germ cells undergo structural and functional changes under the control of several endocrine, paracrine, and autocrine factors (Gnessi et al. 1997, Franca et al. 1998, McLachlan et al. 2002). Among them, estrogens synthesized by the microsomal enzymatic complex aromatase are recognized as potential regulators of spermatogenesis in several species (O'Donnell et al. 2001, Carreau \& Hess 2010).

Gene modification in mice and men has brought us valuable information: a decrease in quantity and quality of spermatids in aromatase-deficient male mice (aromatase knockout; ArKO) was observed, resulting in the infertility of 1-year-old animals (Robertson et al. 1999). Conversely, hypertrophy and hyperplasia of Leydig cells associated with infertility were observed in mice overexpressing aromatase (Li \& Rahman 2008). Moreover, some men with the congenital aromatase deficiency syndrome present impaired quality and quantity of spermatids associated with a reduction in the motility and in the number of spermatozoa (Jones et al. 2006).

In the rat testis, several studies concerning aromatase expression at transcript (Janulis et al. 1996, Levallet \& Carreau 1997, Levallet et al. 1998a,b, Bourguiba et al. 2003a,b, Silandre et al. 2007) and protein levels (Levallet et al. 1998a, Carpino et al. 2001) as well as its biological activity (Levallet et al. 1998a, Bourguiba et al. 2003a,b) have been published. Aromatase is expressed both in the interstitial tissue and in the seminiferous tubules. Sertoli cells are the main source of estrogens in immature rats, whereas in adults, estrogens are synthesized by Leydig and germ cells (Carreau et al. 2009).

Genomic effects of estrogens are mediated by nuclear estrogen receptors (ESRs) ESR1 and ESR2 (Heldring et al. 2007), which are both expressed in testicular cells of 
several species (Carreau \& Hess 2010). However, data concerning their localization in adult rat testis are not consistent. Indeed, ESR1 has been immunodetected only in Leydig cells by Fisher et al. (1997) and by Saunders $\mathrm{et} \mathrm{al}$. (1998), but was also revealed in the seminiferous compartment by Pelletier et al. (2000). About ESR2, all studies are in agreement concerning its localization in seminiferous tubules but data are in conflict regarding its presence in germ cells. While Saunders et al. (1998) and van Pelt et al. (1999) found ESR2 in Sertoli cells and in different germ cell types (spermatogonia, pachytene spermatocytes (PS), and round spermatids (RS)), Pelletier et al. (2000) localized ESR2 was only found in Sertoli cells. ESR transcripts have been studied using in situ hybridization: ESR1 mRNAs have been found in Leydig cells (Mowa \& Iwagana 2001) and spermatids (Pelletier et al. 2000); ESR2 mRNA has been revealed in Sertoli cells and spermatocytes (Shugrue et al. 1998) while van Pelt et al. (1999) retrieved them also in A spermatogonia and RS. It is of note that the presence of ESRs either at transcript or protein level has never been observed in peritubular cells (Fisher et al. 1997, Saunders et al. 1997, 1998, Shugrue et al. 1998, van Pelt et al. 1999, Pelletier et al. 2000, Mowa \& Iwagana 2001).

The synchrony of germ cell development suggests the existence of precise and coordinated cyclic programs of gene expression (Kimmins et al. 2004, Johnston et al. 2008). Indeed, the expression of numerous genes implicated in biological pathways and processes in spermatogenic cells and Sertoli cells is regulated in a stage-dependent manner (Johnston et al. 2008). As several testicular cell types express aromatase and ESRs and since data published are not in accordance, we wish to carefully clarify the expression patterns of aromatase and ESRs in rat testis in relation to age but also in purified germ cells, Sertoli cells, Leydig cells, and in seminiferous tubules at defined stages of the cycle of adult rat. In addition, we enlighten the presence of variants of estrogen receptors ESR1 and ESR2 in the adult testis.

\section{Materials and methods}

\section{Animals}

Sprague-Dawley rats (Janvier, Le Genest Saint-Isle, France) were housed under standard conditions (12 h light:12 h darkness cycle and controlled room temperature) with food and water provided ad libidum. All animal procedures were carried out in accordance with the French Government Regulations (Services Vétérinaires de la Santé et de la Production Animale, Ministère de l'Agriculture) and approved by the local ethical committee of the University of Caen Basse-Normandie.

Sprague-Dawley rats were housed at the Animal Center of Turku University (Turku, Finland) in a controlled environment with access to food and water ad libidum. All experiments were preapproved by the Committee on the Ethics of Animal Experimentation of the University of Turku.

\section{Tissue collection}

Rats (10, 20, 30, 70, and 90 days old) were killed by decapitation either after $\mathrm{CO}_{2}$ anesthesia or not, and tissues (testis, brain, and pituitary) were dissected, placed in PBS, or flash-frozen in liquid nitrogen and stored at $-80{ }^{\circ} \mathrm{C}$ until RNA extraction.

\section{Collection of seminiferous tubules from adult rat testes}

Heterogeneous seminiferous tubules were prepared from decapsulated testes of 70-day-old rats. Interstitial tissue was eliminated mechanically under microscopic control. Seminiferous tubules from decapsulated testes of 90-day-old rats were subjected to transilluminationassisted microdissection as previously described (Toppari \& Parvinen 1985) to collect $5 \mathrm{~cm}$ of each stage or group of stages (I, II-III, IV-V, VI, VIIa-b, VIIc-d, VIII, IX-XI, XII, and XIII-XIV). Samples were flash-frozen and stored at $-80{ }^{\circ} \mathrm{C}$ until RNA extraction.

\section{Purification of immature rat Sertoli cells}

Sertoli cells were isolated from testes of 10-, 20- and 30-day-old rats by sequential enzymatic digestions according to the method described by Dorrington $e t$ al. (1975). Sertoli cells were seeded at a density of 100000 , 200000 , and 650000 cells $/ \mathrm{cm}^{2}$ for $10-, 20$-, and 30-dayold rats respectively, and cultured for $72 \mathrm{~h}$ in Ham's F12/ DMEM (Gibco) supplemented with $2 \%$ ultroser SF (v/v; Biosepra, Cergy-Pontoise, France) in a humidified atmosphere of $5 \% \mathrm{CO}_{2}$ and $95 \%$ air at $32{ }^{\circ} \mathrm{C}$. On day 3 , germ cells were removed by a hypotonic treatment with $20 \mathrm{mM}$ Tris-HCl ( $\mathrm{pH} \mathrm{7.2}$; Sigma), and 5 days after plating, Sertoli cells were rinsed with PBS and stored at $-80{ }^{\circ} \mathrm{C}$ until RNA extraction.

\section{Purification of adult rat Leydig, Sertoli, and germ cells}

Testes of 70-day-old Sprague-Dawley rats were decapsulated and submitted to a first enzymatic digestion with collagenase-dispase $0 \cdot 05 \%$, DNAse $0 \cdot 001 \%$, and soybean trypsin inhibitor (STI) $0.005 \%$ (w/v; Sigma) for $15 \mathrm{~min}$ at $37^{\circ} \mathrm{C}$. After centrifugation, Leydig cells contained in the supernatant were purified on a discontinuous Percoll gradient (Papadopoulos et al. 1985). After several washes in PBS buffer, Leydig cells were stored at $-80{ }^{\circ} \mathrm{C}$ until RNA extraction. The pellet was submitted to a second enzymatic digestion with 
collagenase-dispase $0.05 \%$, DNAse $0.001 \%$, and STI $0.005 \%$ (w/v; Sigma) for $30 \mathrm{~min}$ at $37^{\circ} \mathrm{C}$ and to a final enzymatic digestion with hyaluronidase $0.1 \%$, STI $0.005 \%$, and DNAse $0.001 \%(\mathrm{w} / \mathrm{v}$; Sigma) during $30 \mathrm{~min}$ at $37^{\circ} \mathrm{C}$. After centrifugation, the supernatant and the pellet, containing Sertoli cells and germ cells, were filtered through glass wool to remove spermatozoa. After several washes in PBS buffer, cells were seeded at a density of 650000 cells $/ \mathrm{cm}^{2}$ in Ham's F12/DMEM (Gibco) as previously described by Silandre et al. (2007) and cultured in a humidified atmosphere of $5 \% \mathrm{CO}_{2}$ and $95 \%$ air at $32{ }^{\circ} \mathrm{C}$. After $24 \mathrm{~h}$ of culture, the medium containing germ cells was washed with PBS, and germ cells were purified (PS and RS) by unit gravity sedimentation through a BSA (Roche Diagnostics) gradient $(0 \cdot 2-2 \cdot 75 \% ; \mathrm{w} / \mathrm{v})$ in a Sta-Put apparatus (Bellve et al. 1977). The fractions enriched with PS and RS were identified under microscope as reported elsewhere (Levallet et al. 1998a). To estimate the contamination of the germ cell fractions by Leydig cells, a 33-hydroxysteroid dehydrogenase histochemical staining (Klinefelter et al. 1987), a specific marker of Leydig cells, was realized, showing $<1 \%$ contamination. For both germ cell preparations, the purity was higher than $95 \%$ (the major contamination was by other germ cells; Silandre et al. 2007). Cells were washed with PBS buffer and stored at $-80^{\circ} \mathrm{C}$ until RNA extraction. Sertoli cells were cultured for an additional period of $48 \mathrm{~h}$ in Ham's F12/DMEM (Gibco) supplemented with $2 \%$ ultroser SF (v/v; Biosepra) in a humidified atmosphere of $5 \% \mathrm{CO}_{2}$ and $95 \%$ air at $32{ }^{\circ} \mathrm{C}$, and remaining germ cells were removed by a hypotonic treatment. Five days after plating, Sertoli cells were washed with PBS buffer and stored at $-80{ }^{\circ} \mathrm{C}$ until RNA extraction.

\section{RNA extraction}

The TRI Reagent solution (Sigma) was used to extract total RNA according to the manufacturer's instructions.
The concentration of samples was determined by the absorbance at $260 \mathrm{~nm}$. The purity and the integrity of the RNAs were checked by measuring optical density at 260 and $280 \mathrm{~nm}$ followed by an electrophoresis on $1 \%$ agarose gel stained with $0.01 \%$ ethidium bromide (v/v; Sigma).

\section{Reverse transcription and PCR assay}

Two micrograms of total RNA were reverse transcribed for $90 \mathrm{~min}$ at $37^{\circ} \mathrm{C}$ with $200 \mathrm{IU}$ Moloney murine leukemia virus reverse transcriptase, 20 IU RNasin, $0 \cdot 2 \mu \mathrm{g}$ random hexamers, and $500 \mu \mathrm{M} \mathrm{dNTP}$ in a total volume of $40 \mu \mathrm{l}$. Four microliters of cDNA were used for PCR which was performed using 1.5 IU Taq DNA polymerase (Promega) in a PCR buffer containing $200 \mu \mathrm{M} \mathrm{dNTP}, 1.5 \mathrm{mM} \mathrm{MgCl}$, and $25 \mathrm{pmol}$ of each primer (Eurogentec, Angers, France) in a total volume of $50 \mu \mathrm{l}$. The negative control was realized by adding water instead of cDNA. PCR primers are presented in Table 1. PCRs were performed as follows in the Stratagene Gradient Cycler (Agilent Technologies, Massy, France): an initial step at $95^{\circ} \mathrm{C}$ for 5 min and then 40 cycles of $95{ }^{\circ} \mathrm{C}$ for $30 \mathrm{~s}, 60{ }^{\circ} \mathrm{C}$ for $30 \mathrm{~s}, 72^{\circ} \mathrm{C}$ for $45 \mathrm{~s}$, and a final step of elongation at $72^{\circ} \mathrm{C}$ for $10 \mathrm{~min}$. Resulting PCR products were separated by electrophoresis on a $2 \%(\mathrm{w} / \mathrm{v})$ agarose gel stained with $0.01 \%$ (v/v) ethidium bromide (Sigma).

\section{Purification of PCR products}

PCR fragments were eluted from the agarose gel and purified using Wizard SV Gel and PCR Clean-Up System (Promega) according to the manufacturer's instructions.

\section{Reverse transcription and real-time PCR assay}

In total, $250 \mathrm{ng}$ of total RNA were reverse transcribed for $90 \mathrm{~min}$ at $37^{\circ} \mathrm{C}$ with $100 \mathrm{IU}$ Moloney Murine

Table 1 Sequences of oligonucleotides used for PCR

Gene (GenBank accession number)

$\mathrm{ER} \alpha(\mathrm{X} 61098)$

$\operatorname{ER} \beta(U 57439)$

ERß2 (AF042059.1)
Primers name, position, and sequence

\begin{tabular}{|c|}
\hline $\begin{array}{l}5^{\prime} E R \propto 5^{\prime}-610 \text { GATCATGGAGTCTGCCAAGG } \\
3^{\prime} E R \propto 5^{\prime}-{ }_{1495} \text { CAGAGACTTCAAGGTGCTGGA }\end{array}$ \\
\hline $\begin{array}{l}5^{\prime} E R \alpha \text { (nested) } 5^{\prime}-772 \text { CATCGATAAGAACCGGAGGA } \\
3^{\prime} E R \alpha \text { (nested) } 5^{\prime}-1245 \text { ATCTCCAACCAGGCACACTC }\end{array}$ \\
\hline $\begin{array}{l}5^{\prime} E R \beta 5^{\prime}{ }^{\prime}{ }_{657} \text { GAGGAAGCTTAGTGGGAGCA } \\
3^{\prime} E R \beta 5^{\prime}{ }_{1426} \text { GCCAGGAGCATGTCAAAGAT }\end{array}$ \\
\hline $\begin{array}{l}5^{\prime} E R \beta \text { (nested) } 5^{\prime}-751 \text { CTGGGTATCATTACGGCGTT } \\
3^{\prime} E R \beta \text { (nested) } 5^{\prime}-{ }_{1404} \text { CCAGAATCCCTTCTACGCAC }\end{array}$ \\
\hline $\begin{array}{l}5^{\prime} E R \beta \text { (nested) 5'-751 CTGGGTATCATTACGGCGTT } \\
3^{\prime} E R \beta 25^{\prime}-979 \text { GCCAGTGAGGGTCTTCTGAG }\end{array}$ \\
\hline
\end{tabular}


Table 2 Sequences of oligonucleotides used for real-time PCR and size of PCR products

\begin{tabular}{|c|c|c|}
\hline Gene (GenBank accession number) & Primer name, position, and sequence & Size of PCR product (bp) \\
\hline L19 (NM_031103) & 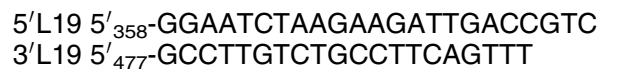 & 120 \\
\hline Aromatase (M33986) & $\begin{array}{l}5^{\prime} \text { Aro } 5^{\prime}{ }_{1546} \text {-CGTCATGTTGCTTCTCATCG } \\
3^{\prime} \text { Aro } 5^{\prime}{ }_{1695} \text {-TACCGCAGGCTCTCGTTAAT }\end{array}$ & 150 \\
\hline ESR1 (X61098) & $\begin{array}{l}5^{\prime} \text { ESR } 15^{\prime}{ }_{545} \text {-AATTCTGACAATCGACGCCAG } \\
3^{\prime} \text { ESR } 15^{\prime}{ }_{889} \text {-GTGCTTCAACATTCTCCCTCCTC }\end{array}$ & 345 \\
\hline ESR2 (U57439) & $\begin{array}{l}5^{\prime} \text { ESR2 5' } 5_{2107}^{\prime} \text {-CTTGCCCACTTGGAAACATC } \\
3^{\prime} \text { ESR2 5' } 5_{2258}^{\prime} \text {-CCAAAGGTTGATTTTATGGCC }\end{array}$ & 152 \\
\hline
\end{tabular}

Leukemia Virus Reverse Transcriptase, 10 IU RNasin, $0.1 \mu \mathrm{g}$ random hexamers, and $500 \mu \mathrm{M}$ dNTP (Promega) in a total volume of $20 \mu$ l. Five microliters of diluted cDNA (1:20) were used for quantitative PCR with $10 \mu \mathrm{l}$ of $2 \times \mathrm{iQ} \mathrm{SYBR}$ Green Supermix (Bio-Rad) and $0.25 \mu \mathrm{M}$ of each primer (Eurogentec) in a total volume of $20 \mu \mathrm{l}$. The negative control was realized by adding water instead of diluted cDNA. Primers were designed to be placed on different exons except for ESR2 primers, and are presented in Table 2. PCR was performed as follows in the iCycler IQ real-time PCR detection system (Bio-Rad): an initial step at $95^{\circ} \mathrm{C}$ for $2 \mathrm{~min}$ and $30 \mathrm{~s}$ and then 45 cycles of $95^{\circ} \mathrm{C}$ for $10 \mathrm{~s}$ and $60{ }^{\circ} \mathrm{C}$ for $60 \mathrm{~s}$. At the end of the amplification, an increase in $0.5^{\circ} \mathrm{C}$ every $10 \mathrm{~s}$ from 50 to $95^{\circ} \mathrm{C}$ allowed to obtain the melt curve. PCR efficiency, measured for each set of primers using a range dilution of reverse transcription (RT) products $(1: 5,1: 10 ; 1: 20 ; 1: 50$; 1:100), was comprised between 96 and $105 \%$. Relative levels of specific mRNA were obtained with the formula $2^{-\left(C_{\mathrm{t}} \text { gene }-C_{\mathrm{t}} \text { ref }\right)}$, the reference being L19 transcripts (Tena-Sempere et al. 2002).

\section{Sequence analyses}

Each cDNA amplified was sequenced (Cogenics, Takeley, UK). Then, the sequences were subjected to Basic Local Alignment Search Tool (BLAST) homology search (www.ncbi.nlm.nih.gov/BLAST/; Altschul et al. 1990).

\section{Statistical analysis}

Results are means \pm s.E.M. of three to five experiments, each sample performed in duplicates. Statistical analysis was performed using the software GraphPad Instat (GraphPad Software, San Diego, CA, USA). One-way ANOVA followed by a Tukey test (comparison of at least three groups of data) or unpaired Student's $t$-test (comparison of two groups of data) was used to identify significant differences. Statistical significance was accepted at $P \leq 0 \cdot 05$.

\section{Results}

\section{Evolution of aromatase gene expression in rat testis}

The aromatase mRNA expression in Sertoli cells was low at 10 days; it was four times higher in cells from 20-day-old rats, and at 30 days it fell to the same level as observed at 10 days. In adult, aromatase transcripts were undetectable in Sertoli cells in our experimental conditions (Fig. 1), whereas the seminiferous tubules contained similar levels as the Leydig cells (Fig. 2A). In whole gonad, the levels of aromatase mRNA increased between 10 and 30 days of age and remained at that level in the adult testis (data not shown), suggesting a germ cell expression of that enzyme. Indeed, the aromatase mRNA level was twofold higher in PS compared with RS (Fig. 2B). Within the seminiferous tubules, the aromatase expression varied according to the stages of the seminiferous epithelium: it began to increase in stage XIII and reached its maximum at stage I, whereafter it progressively decreased until stage IV and was stable until stage XII (Fig. 2C).

\section{Evolution of ESR1 gene expression and identification of variants in the rat testis}

In order to study the ESR1 expression in the rat testis, we used primers designed to amplify the sequence coding for DNA-binding domain (Table 2). Changes in the expression of ESR1 transcripts in the whole testis

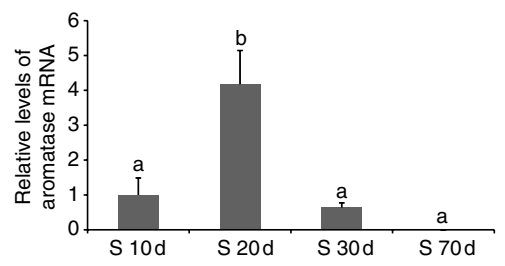

Figure 1 Aromatase gene expression in rat Sertoli cells according to age. Measures were done using real-time RT-PCR. Results are expressed as means \pm S.E.M. $(n=3)$. The average value for $S 10 \mathrm{~d}$ is fixed at 1 , and different letters $(a$ and $b$ ) denote significant differences $(P \leq 0.01)$. S, Sertoli cells and d, days. 

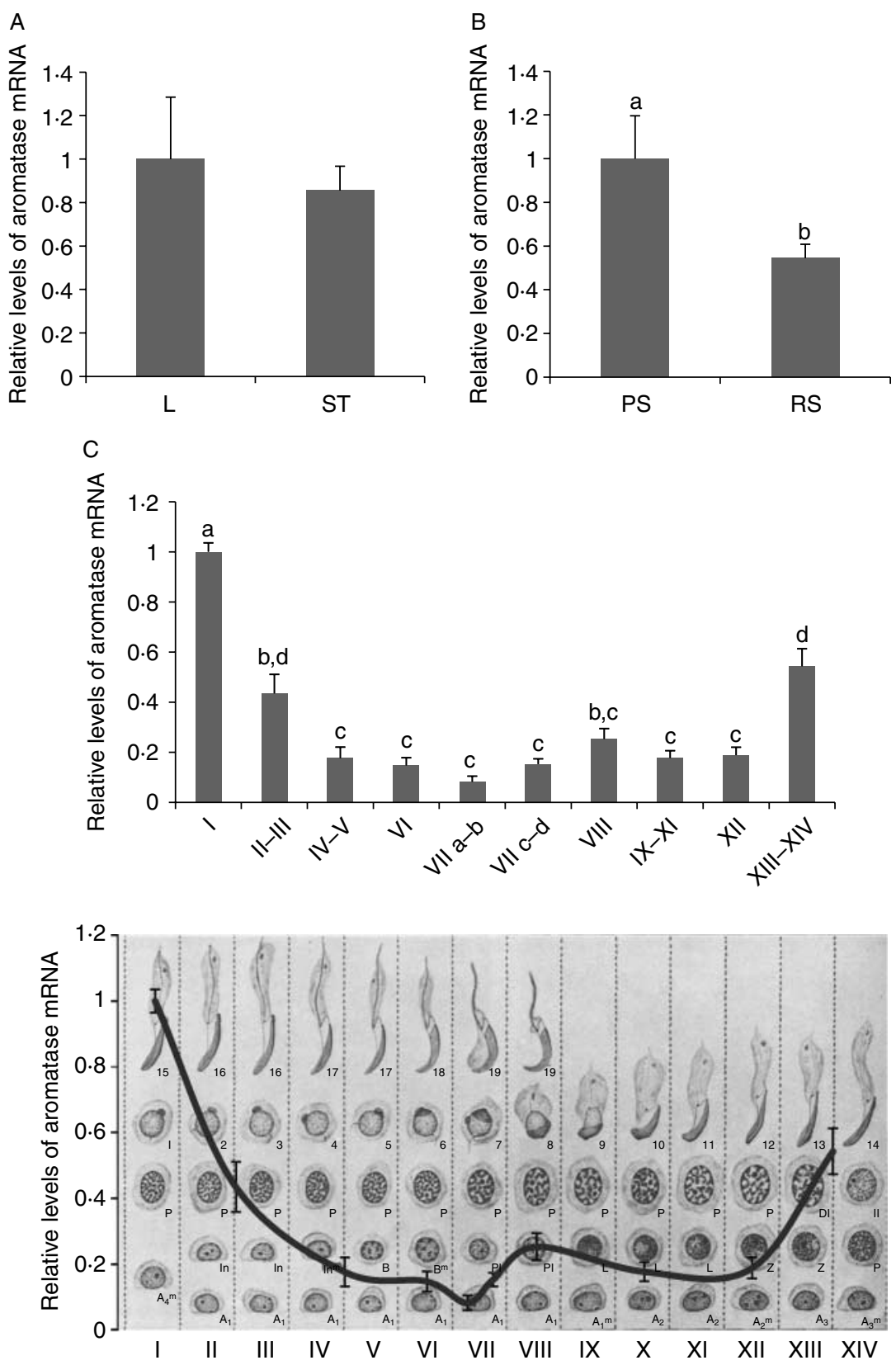

Figure 2 Aromatase gene expression according to compartment $(A)$, to germ cell type (B), and to the stage of the seminiferous epithelium $(C)$ of the adult rat testis. Measures were done using real-time RT-PCR. (A) Results are expressed as means \pm S.E.M. $(n=3)$, and the average value for $L 70 d$ is fixed at 1 . (B) Results are expressed as means \pm S.E.M. $(n=5)$, the average value for $P S$ is fixed at 1 , and different letters ( $a$ and $b$ ) denote significant difference $(P \leq 0.05)$. (C) Results are expressed as means \pm S.E.M. $(n=4)$, the average value for stage I is fixed at 1 , and different letters $(a, b, c$, and d) denote significant differences $(P \leq 0.05)$. L, Leydig cells; ST, seminiferous tubules; PS, pachytene spermatocyte; RS, round spermatid and d, days.

during development were observed: their levels did not vary between 10 and 30 days, whereas there was a sevenfold increase between 30 and 70 days (Fig. 3A). In Sertoli cells, the amount of mRNA increased eightfold from 10 to 30 days, whereas in adult cells, the transcript levels fell to the same level as recorded at 10 and 20 days of age (Fig. 3B). In the adult, ESR1 mRNA level was sixfold higher in the seminiferous tubules than in the 

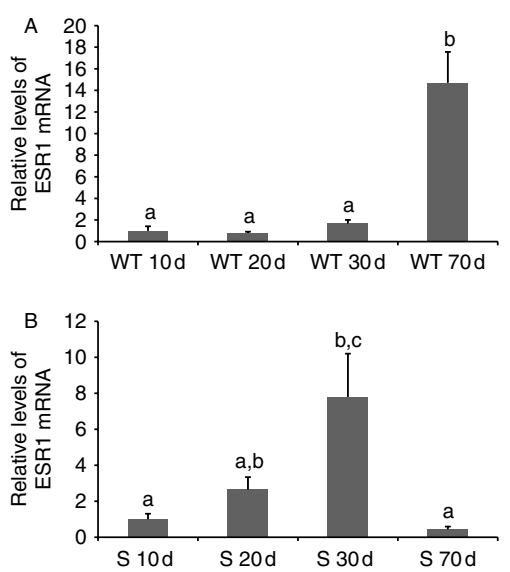

Figure 3 ESR1 gene expression in the whole rat testis $(A)$ and in rat Sertoli cells (B) according to the age. Measures were done using real-time RT-PCR. Results are expressed as means of three experiments \pm S.E.M. (A) The average value for WT $10 \mathrm{~d}$ is fixed at 1 , and different letters ( $a$ and $b)$ denote significant differences $(P \leq 0.001)$. (B) The average value for $\mathrm{S} 10 \mathrm{~d}$ is fixed at 1 , and different letters $(a, b$, and $c)$ denote significant differences $(P \leq 0.05)$. WT, whole testis; S, Sertoli cells and d, days.

Leydig cells (Fig. 4A). In germ cells, ESR1 expression was fourfold higher in RS than in PS (Fig. 4B). In the seminiferous tubules, ESR1 expression was low in stages I-VIIa-b and then increased starting at stage VIIc-d until stage VIII (20-fold higher in stage VIII than in stage VIIa-b), and the level of expression was maintained until stage XIV (Fig. 4C).

$\mathrm{ER} \alpha \mathrm{mRNA}$ spliced variants have been reported in rat tissues (Friend et al. 1997), and thus, we designed primers flanking putative deleted regions to check the presence of these variants in the testis (Table 1). In the rat brain, the fragments of 886 and $613 \mathrm{bp}$ correspond to the size expected for the full-length form and for the form deleted of exons 5 and 6, ER $\alpha \delta 5,6$ respectively (Friend et al. 1997). In the testis, two fragments of 886 and $550 \mathrm{bp}$ were observed (Fig. 5). After sequencing using internal primers (Table 1), the sequence obtained from the 886-bp fragment presented 99\% of homology with ESR1 sequence (X61098). The sequence obtained from the 550-bp fragment had a homology of $100 \%$ with ESR1 sequence with deleted exon 4 (X61098). The sequence of this variant was submitted to GenBank (GU111761).

\section{Evolution of ESR2 gene expression and identification of variants in the rat testis}

Although it seems to have an increase in the 70-day-old whole testis, there was no significant difference in ESR2 expression within the whole testis (Fig. 6A). In Sertoli cells, there was no significant change in ESR2 expression between 10 and 30 days; however, a significant increase of 20 -fold at 70 days was observed (Fig. 6B). In adult testis, ESR2 was expressed at the same level in the seminiferous tubules and in the Leydig cells (Fig. 7A), whereas the receptor was four times more expressed in RS than in PS (Fig. 7B). There were no significant differences according to the stages of the seminiferous epithelium (Fig. 7C).

Petersen et al. (1998) have described several ER $\beta$ spliced variants in rat tissues. Using primers flanking the variable region of ESR2 mRNA previously described (Table 1), we amplified four cDNAs in the rat testis and pituitary (Fig. 8). The sizes of the PCR products in the pituitary and in the testis were $825,771,708$, and $654 \mathrm{bp}$, which correspond to the sizes expected for ER $\beta 2$, ER $\beta 1$, ER $\beta 2 \delta 3$, and ER $\beta 1 \delta 3$ respectively. After sequencing using internal primers ( $5^{\prime}$-ER $\beta$ (nested)/ $3^{\prime}$-ER $\beta$ (nested) for ER $\beta 1$ and ER $\beta 1 \delta 3$, and $5^{\prime}$-ER $\beta$ (nested) $/ 3^{\prime}$-ER $\beta 2$ for ER $\beta 2$ and ER $\beta 2 \delta 3$ (Table 1)), the sequences presented at least $98 \%$ of homology with the ERß2 (AF042059.1), ER $\beta 1$ (U57439), ER $\beta 2 \delta 3$ (AF042061.1), and ERß183 sequences (AF0420690.1) respectively.

\section{Discussion}

Our data have shown that the aromatase expression is not only regulated according to age and cell type but also in relation to the stages of the seminiferous epithelium, the maximum being observed between stages XIII and III.

As previously reported (Silandre et al. 2007), the aromatase expression in the whole testis was regulated according to age: it increased between 10 and 30 days, and was maximal from 30 days onwards. However, the maximal expression of aromatase in Sertoli cells was observed at 20 days, and then decreased until being undetectable at 70 days. This decrease of the aromatase expression in the adult Sertoli cells could be explained by a negative control of Sertoli cell aromatase expression by germ cells via paracrine regulatory factors (Boitani et al.1981, Silandre et al. 2007, Bouraïma-Lelong et al. 2010). In adult animals, the aromatase gene expression ensured, in part, by germ cells (up to 50\%) and by Leydig cells was demonstrated (Carreau \& Hess 2010). This expression was dependent of germ cell type and mainly supported by PS (Silandre et al. 2007; our results). Stage-specific expression pattern should reflect transcript levels in germ cells, i.e. late spermatocytes and early RS, and it was reported that despite the protein being localized in PS and RS (Carpino et al. 2001), the aromatase activity was weak in PS and progressively increased until it reached a maximum in spermatozoa (Levallet et al. 1998a). This delay between transcript expression and protein activity could be explained by the fact that decoupling between 

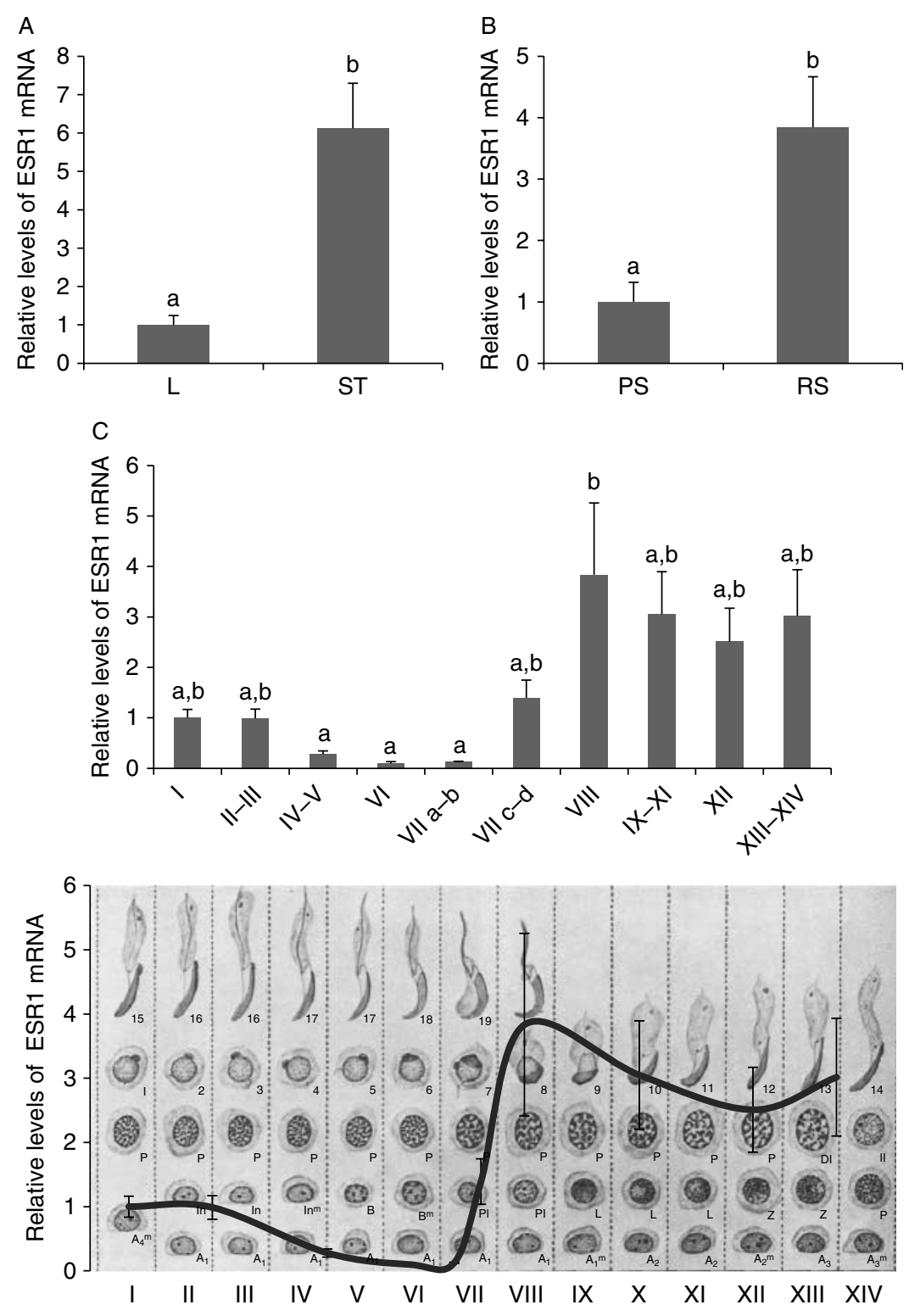

Figure 4 ESR1 gene expression according to the compartment $(A)$, to the germ cell type $(B)$, and to the stage of the seminiferous epithelium $(C)$ of the adult rat testis. Measures were done using real-time RT-PCR. (A) Results are expressed as means of three experiments \pm S.E.M., the average value for $L 70 \mathrm{~d}$ is fixed at 1 , and different letters $(\mathrm{a}$ and $\mathrm{b})$ denote significant differences $(P \leq 0.001)$. (B) Results are expressed as means of five experiments \pm S.E.M., the average value for $P S$ is fixed at 1 , and different letters $(\mathrm{a}$ and $\mathrm{b})$ denote significant difference $(P \leq 0.01)$. (C) Results are expressed as means of four experiments \pm S.E.M., the average value for stage $I$ is fixed at 1 , and different letters ( $\mathrm{a}$ and $\mathrm{b})$ denote significant differences $(P \leq 0.05)$. Leydig cells; ST, seminiferous tubules; PS, pachytene spermatocyte; RS, round spermatid and d, days.

transcription and translation was a main characteristic of spermatogenic cells (Dadoune 1994, Eddy 2002), and by the fact that the aromatase (a glycoprotein) undergoes several posttranslational modifications like glycosylations (Sethumadhavan et al. 1991).
Concerning the nuclear receptor ESR1, we have demonstrated that the transcripts varied according 1) to age, 2) to the germ cell type, and 3) to the stage of the seminiferous epithelium, whereas the ESR2 expression seemed to be less concerned. The ESR1 


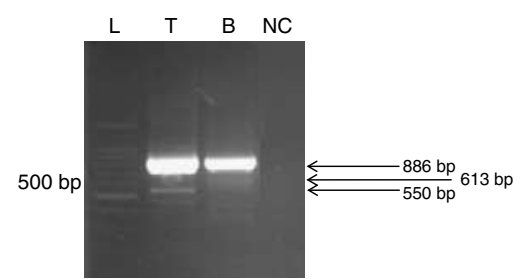

Figure 5 ESR1 variants in the rat adult testis. Primers of both sides of the variable region of ER $\alpha$ mRNA were designed. Forty cycles of PCR were performed, and PCR products were separated on $1.5 \%$ agarose gel during $45 \mathrm{~min}$. L, ladder; $T$, testis; $B$, brain; NC, negative control.

expression strongly increased between 30 and 70 days in the adult whole testis, although it drastically decreased in Sertoli cells during the same time, explained by the presence of ESR1 transcripts in Leydig cells and in germ cells. Mowa \& Iwagana (2001) reported ESR1 messengers only in Leydig cells; however, our results are in accordance with those of Pelletier et al. (2000) who demonstrated the presence of ESR1 transcripts using in situ hybridization in developing spermatids. The increase of mRNAs in RS could be due to the use of a specific testis promoter. In fact, it was described that ESR1 transcripts can contain different $5^{\prime}$-UTR extremities arising from the utilization of various promoters as demonstrated in the human testis (Brand et al. 2002). This mechanism was described for the regulation of the expression of numerous genes (Eddy 2002) including the aromatase gene (Silandre et al. 2007). The ESR2 expression seemed to be more elevated in the adult testis, which could be explained by

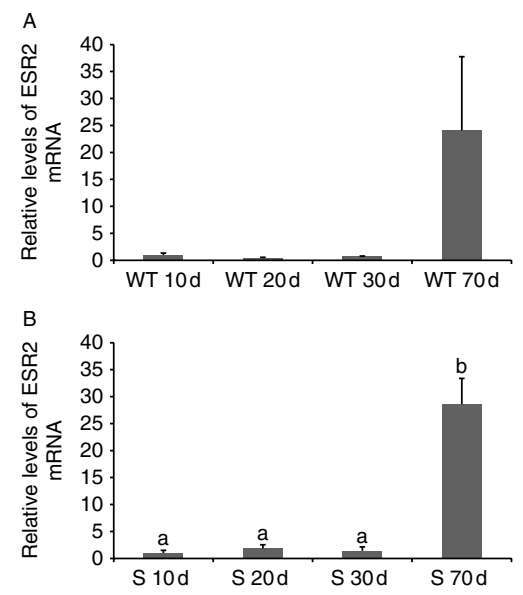

Figure 6 ESR2 gene expression in the whole rat testis $(A)$ and in rat Sertoli cells $(B)$ according to age. Measures were done using real-time RT-PCR. Results are expressed as means \pm s.E.M. $(n=3)$. (A) The average value for WT $10 \mathrm{~d}$ is fixed at 1 . (B) The average value for $S 10 \mathrm{~d}$ is fixed at 1 , and different letters ( $a$ and $b$ ) denote significant difference $(P \leq 0 \cdot 001)$. WT, whole testis; $S$, Sertoli cells and d, days. its presence in germ cells (especially in RS) and in adult Sertoli cells. Conversely, ESR1 was highly expressed in Sertoli cells from young animals suggesting a switch of ESR expression in these cells. In addition, both ESR1 and ESR2 were more expressed in adult testes, suggesting a putative effect of estrogens in adult spermatogenesis. Indeed, the disruption of the ESR1 gene in mice induced infertily due to a lack of fluid resorption in efferent ducts and in the proximal part of the epididymis (Eddy et al. 1996) leading to an increase in spontaneous acrosome reactions and defects of flagellar (Joseph et al. 2010). Antal et al. (2008) demonstrated that ESR2 gene knock-out (ESR2KO) mice were infertile, despite the absence of histological abnormalities in the testis and normally mobile spermatozoa. Conversely, in the study from Krege et al. (1998), ESR2KO mice were fertile, and showed no apparent morphological or functional abnormalities in the testis possibly due to the presence of ESR2 forms lacking exon 3 which were still expressed in this model. It is of note that these studies were not realized in rats but in mice and phenotypes observed cannot be exactly transferred from one species to another. Moreover, expression of both ESRs is highly variable between species (Carreau \& Hess 2010). In addition to Sertoli cells, Leydig cells and germ cells of adult animal expressed the ESR2, and as ESR1, its transcripts level was higher in RS than in PS. However, ESR2 expression was lower than that of ESR1 in adult seminiferous tubules (16-fold more ESR1 transcripts compared with ESR2). The ESR2 expression seemed to increase with the maturation degree of germ cells. In fact, van Pelt et al. (1999) found more transcripts in PS and RS compared with type A spermatogonia, which was supported by our data showing higher ESR2 mRNA levels in RS compared with PS. The fact that no significant variations of ESR2 expression were observed according to the stages of the seminiferous epithelium could be explained by its weak but widespread expression in somatic and germ cells (Pelletier et al. 2000, Mowa \& Iwagana 2001; our results). Unlike previous data (Shugrue et al. 1998, van Pelt et al. 1999, Mowa \& Iwagana 2001), the amount of detected ESR2 messengers in Leydig cells was identical to that in seminiferous tubules.

The presence of variants of both ESR1 and ESR2 (Fig. 9; Friend et al. 1997, Shupnik 2002) could explain the variability of the results in the quantification of their messengers. Three in-frame deletions of ESR1 have been reported (Fig. 9A): deletion of exon 4 (ER $\alpha \delta 4)$, deletion of exons 3 and $4(\mathrm{ER} \alpha \delta 3,4)$, and deletion of exons 5 and 6 (ER $\alpha \delta 5,6$; Skipper et al. 1993, Friend et al. 1997, Shupnik 2002). Although Friend et al. (1997) reported $\mathrm{ER} \alpha \delta 4$ and $\mathrm{ER} \alpha \delta 5,6$ in the testis with the full-length form, we only found the form deleted of exon 4. This deletion occurring in DNA and in 

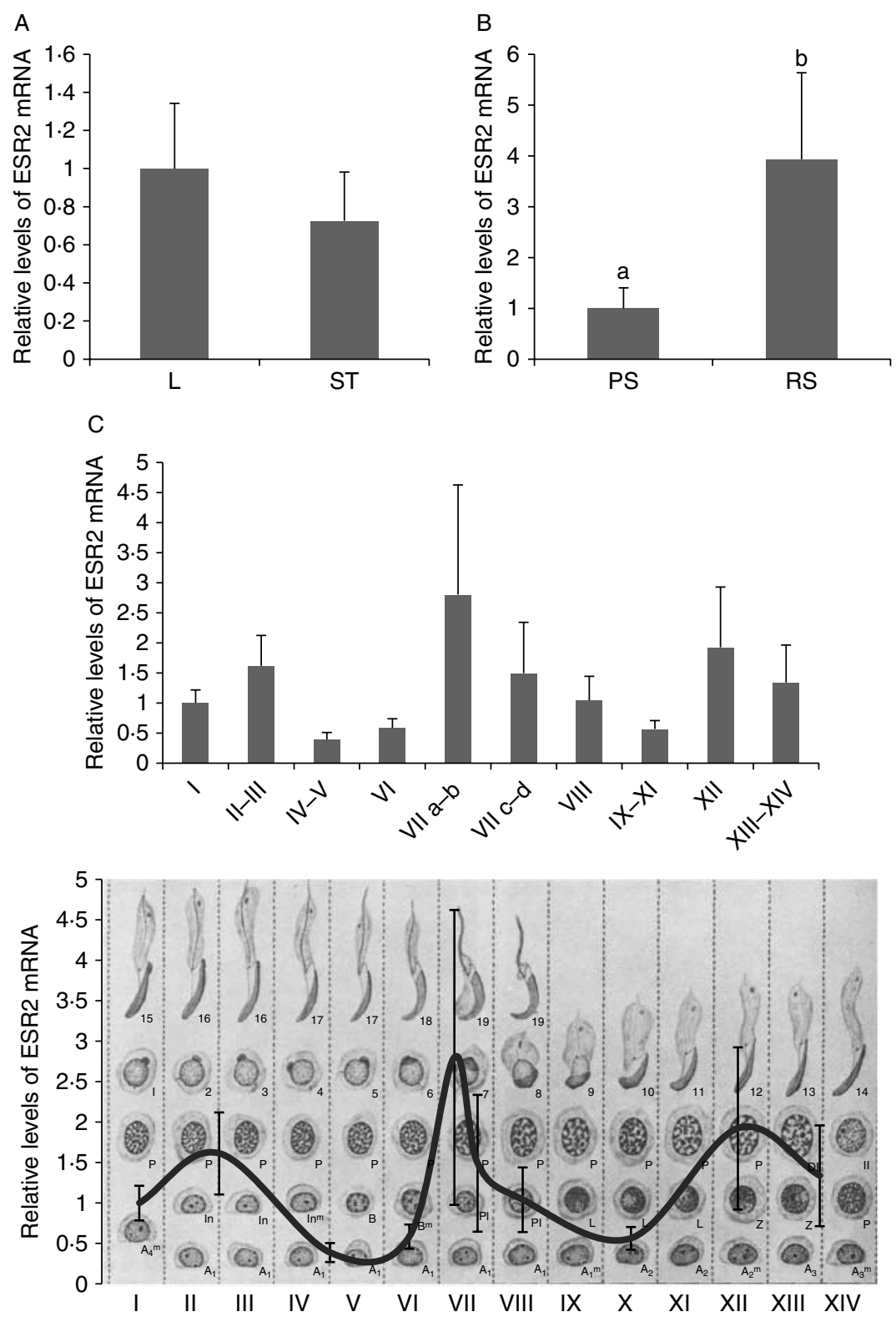

Figure 7 ESR2 gene expression according to compartment (A), to germ cell type (B), and to the stage of the seminiferous epithelium (C) of the adult rat testis. Measures were done using real-time RT-PCR. (A) Results are expressed as means \pm s.E.M. $(n=3)$, and the average value for $L 70 \mathrm{~d}$ is fixed at 1 . (B) Results are expressed as means \pm S.E.M. $(n=5)$, the average value for PS is fixed at 1 , and different letters ( $a$ and b) denote significant difference $(P \leq 0 \cdot 05)$. (C) Results are expressed as means \pm S.E.M. $(n=4)$, and the average value for stage I is fixed at 1 . L, Leydig cells; ST, seminiferous tubules; PS, pachytene spermatocyte; RS, round spermatid; d, days.

hormone-binding domains suggested a modification of receptor activity. However, although smaller $\mathrm{ER} \alpha$ forms were observed in other rat tissues (Geffroy-Roisne et al. 1992, Friend et al. 1997), the authors did not conclude that these proteins correspond to splice variants. Using a specific antibody directed against the C-terminal region of the ESR1 protein, only the full-length form was detected by Chimento et al. (2010) in the whole adult rat testis and in purified germ cells as reported in immature rat Sertoli cells (Lucas et al. 2008). 


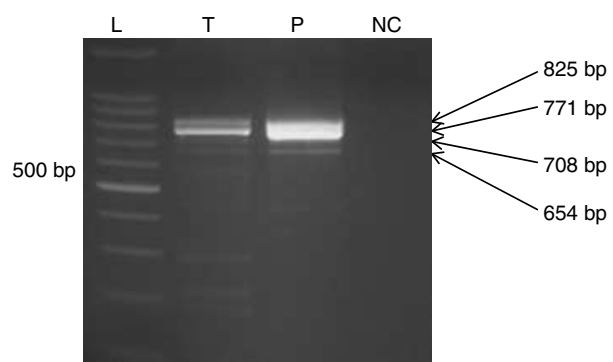

Figure 8 ESR2 variants in the rat adult testis. Primers of both sides of the variable region of ER $\beta$ mRNA were designed. Forty cycles of PCR were performed, and PCR products were separated on $1.5 \%$ agarose gel during $45 \mathrm{~min}$. LM, ladder; $\mathrm{T}$, testis; P, pituitary; NC, negative control.

Regarding ER $\beta$, five different mRNAs were described by Price et al. (2000) (Fig. 9B): ER $\beta 2$ corresponds to ER $\beta 1$ containing an insertion of 54 nucleotides in the exon 6 , which encodes a part of the ligand-binding domain (Maruyama et al. 1998, Petersen et al. 1998). Deletions of exon 3 (partial deletion of DNA-binding domain) lead to the formation of ER $\beta 1 \delta 3$ and ER $\beta 2 \delta 3$ (Petersen et al. 1998). Moreover, a deletion of exon 4 (partial deletion of the hinge region and of the hormone-binding domain) leading to the formation of ER $\beta 1 \delta 4$ was described (Price et al. 2000). Studies on the activity of these receptors were carried out: proteins arising from messengers with the insertion of 54 nucleotides exhibited a ligand affinity weaker than those without. In addition, the deletion of the exon 3 induced a decrease in transcriptional activity (Petersen et al. 1998). Concerning ER $\beta \delta 4$, it was localized in the cytoplasm, whereas other forms were found in the nucleus, and this protein was not able to bind estradiol (Price et al. 2000). Although the majority of ER $\alpha$, ER $\beta 1$, and ER $\beta 2$ transcripts seemed to be in the testis, splice variants may contribute to the estradiol response, although internal exon deletion ESR1 mRNA forms do not exhibit steroid regulation (Friend et al. 1997). However, only one ESR2 protein was detected in the rat testis (Tirado et al. 2004, Lucas et al. 2008, Chimento et al. 2010). The transcript variants of rat ESR1 and ESR2 are issued from a single gene localized on chromosome 1 and chromosome 6 respectively (http://blast.ncbi.nlm.nih.gov/Blast.cgi). In men, six variants were described in the testis (Aschim et al. 2004),

A

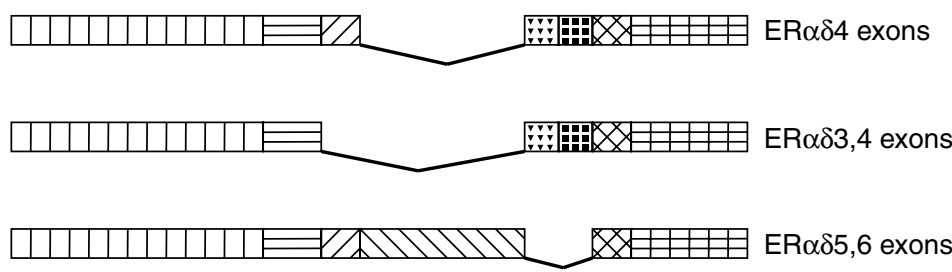

B
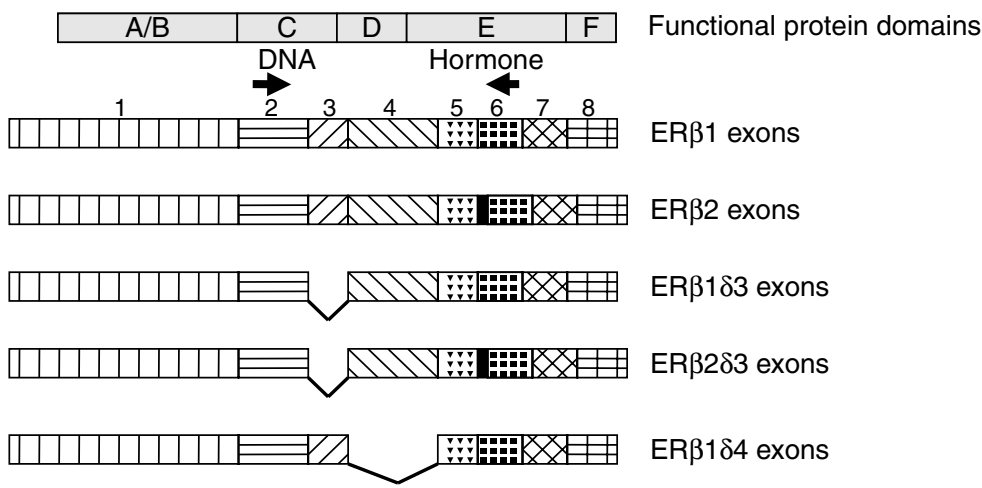

Figure 9 Schematic representation of rat ESR1 variants (Friend et al. 1997) (A) and ESR2 variants (Shupnik 2002) (B). Black arrows represent primer position, and black rectangle represents the insertion of 54 nucleotides; numbers $1-8$ correspond to exons. 
and their differential localization suggests that they could have specific functions in spermatogenesis.

Data concerning the evolution of the aromatase activity in germ cells have revealed that the biological aromatase activity was more elevated in RS than in PS (Levallet et al. 1998a, Bourguiba et al. 2003a,b), and we have shown that the expression of both ESRs evolved in the same manner. This may suggest that the expression of ESRs mRNAs could be regulated by estradiol, and a putative role of ESRs to mediate estrogen effects in spermatogenesis is becoming obvious. In that respect, previous studies have shown that estrogens can regulate the expression of ESR1 mRNA (full-length and variants) and particularly in pituitary cells (Friend et al. 1997, Schaussi et al. 2003, Bryant et al. 2006).

However, we cannot forget that estrogens can also exert rapid effects called 'nongenomic' activating signaling pathways. One of these receptors, $G$ proteincoupled receptor 30 (GPR30) is a seven-transmembrane receptor. Estrogens and agonists were shown to induce MAPK activation and signaling via adenylyl cyclase by this receptor (Prossnitz et al. 2007). Moreover, GPR30 was shown to be involved in proliferative effects of $17 \beta$-estradiol in a mouse spermatogonial cell line GC-1 (Sirianni et al. 2008). In our laboratory, we have found that both GPR30 and ESR1 were involved in the control of apoptosis in PS by 17ß-estradiol (Chimento et al. 2010). Thus, it would be helpful to map GPR30 expression within the testis in order to investigate the part of rapid effects of estrogens in spermatogenesis.

While ESR2 seems less precisely regulated than ESR1, both ESRs are essential for fertility. Thus, it is necessary to deepen their mechanism(s) of action within testis. Moreover, membrane ESRs could be implicated in the nongenomic effects of estrogens (Chimento et al. 2010). Within the rat testis, there is precise regulation of the amount of aromatase and of ESR1 transcripts. Thus, a role of estrogens via nuclear ESR1 in the latest steps of spermatogenesis could be evoked which is in keeping with elevated aromatase activity (Levallet et al. 1998a).

\section{Declaration of interest}

The authors declare that there is no conflict of interest that could be perceived as prejudicing the impartiality of the research reported.

\section{Funding}

C Bois is supported by a fellowship from the French Ministère de l'Enseignement Supérieur et de la Recherche. L Zanatta has a fellowship of CAPES/COFECUB grant Sv:554/07. This work was supported by the French Ministère de l'Enseignement Supérieur et de la Recherche and by the Institut National de la Recherche Agronomique.

\section{Author contribution statement}

C Bois realized all molecular studies and participated with L Zanatta in the preparations of cells. M Nurmio, M Parvinen, and J Toppari prepared the different groups of seminiferous tubules stages. C Delalande and S Carreau supervised this work.

\section{Acknowledgements}

The authors would like to thank E Clair and C Travert for providing Leydig cells.

\section{References}

Altschul SF, Gish W, Miller W, Myers EW \& Lipman DJ 1990 Basic local alignment search tool. Journal of Molecular Biology 215 403-410.

Antal MC, Krust A, Chambon P \& Mark M 2008 Sterility and absence of histopathological defects in nonreproductive organs of a mouse ERß-null mutant. PNAS 105 2433-2438.

Aschim EL, Saether T, Wiger R, Grotmol T \& Haugen TB 2004 Differential distribution of splice variants of estrogen receptor beta in human testicular cells suggests specific functions in spermatogenesis. Journal of Steroid Biochemistry and Molecular Biology 92 97-106.

Bellve AR, Millette CF, Bhatnagar YM \& O'Brien DA 1977 Dissociation of the mouse testis and characterization of isolated spermatogenic cells. Journal of Histochemistry and Cytochemistry 25 480-494.

Boitani C, Ritzén EM \& Parvinen M 1981 Inhibition of rat Sertoli cell aromatase by factor(s) secreted specifically at spermatogenic stages VII and VIII. Molecular and Cellular Endocrinology 23 11-21.

Bouraïma-Lelong H, Vanneste M, Delalande C, Zanatta L, Wolczynski S \& Carreau S 2010 Aromatase gene expression in immature rat Sertoli cells: age-related changes in the FSH signaling pathway. Reproduction, Fertility, and Development 22 508-515.

Bourguiba S, Chater S, Delalande C, Benahmed M \& Carreau S $2003 a$ Regulation of aromatase gene expression in purified germ cells of adult male rats: effects of transforming growth factor $\beta$, tumor necrosis factor $\alpha$, and cyclic adenosine $3^{\prime}, 5^{\prime}$-monophosphate. Biology of Reproduction 69 592-601.

Bourguiba S, Lambard S \& Carreau S $2003 b$ Steroids control the aromatase gene expression in purified germ cells from the adult male rat. Journal of Molecular Endocrinology 31 83-94.

Brand H, Kos M, Denger S, Flouriot G, Gromoll J, Gannon F \& Reid G 2002 A novel promoter is involved in the expression of estrogen receptor alpha in human testis and epididymis. Endocrinology 143 3397-3404.

Bryant WM, Gibson MA \& Shupnik MA 2006 Stimulation of the novel estrogen receptor-alpha intronic TERP-1 promoter by estrogens, androgen, pituitary adenylate cyclase-activating peptide, and forsokolin, and autoregulation by TERP-1 protein. Endocrinology 147 543-551.

Carpino A, Pezzi V, Rago V, Bilinska B \& Ando S 2001 Immunolocalization of cytochrome $\mathrm{P} 450$ aromatase in rat testis during postnatal development. Tissue and Cell 33 349-353.

Carreau S \& Hess R 2010 Oestrogens and spermatogenesis. Philosophical Transactions of the Royal Society of London. Series B $\mathbf{3 6 5}$ 1517-1535.

Carreau S, Delalande C \& Denis-Galeraud I 2009 Mammalian sperm quality and aromatase expression. Microscopy Research and Technique $72552-557$.

Chimento A, Sirianni R, Delalande C, Silandre D, Bois C, Andò S, Maggioloni M, Carreau S \& Pezzi V 2010 17 $\beta$-estradiol activates rapid signaling pathways involved in rat pachytene spermatocytes apoptosis through GPR30 and ER alpha. Molecular and Cellular Endocrinology 320 136-144. 
Dadoune JP 1994 The cellular biology of mammalian spermatids: a review. Bulletin de l'Association des Anatomistes 78 33-40.

Dorrington JH, Roller NF \& Fritz IB 1975 Effects of follicle-stimulating hormone in cultures of Sertoli cells preparations. Molecular and Cellular Endocrinology 3 57-70.

Eddy EM 2002 Male germ cell expression. Recent Progress in Hormone Research 57 103-128.

Eddy EM, Washburn TF, Bunch DO, Goulding EH, Gladen BC, Lubahn DB \& Korach KS 1996 Targeted disruption of the estrogen receptor gene in male mice causes alteration of spermatogenesis and infertility. Endocrinology 137 4796-4805.

Fisher JS, Millar MR, Majdic G, Saunders PT, Fraser HM \& Sharpe RM 1997 Immunolocalisation of estrogen receptor-alpha within the testis and excurrent ducts of the rat and marmoset monkey from perinatal life to adulthood. Journal of Endocrinology 153 485-495.

Franca LR, Ogawa T, Avarbock MR, Brinster RL \& Russell LD 1998 Germ cell genotype controls cell cycle during spermatogenesis in the rat. Biology of Reproduction 59 1371-1377.

Friend KE, Resnick EM, Ang LW \& Shupnik MA 1997 Specific modulation of estrogen receptor mRNA isoforms in rat pituitary throughout the estrous cycle and in response to steroid hormones. Molecular and Cellular Endocrinology 131 147-155.

Geffroy-Roisne S, Duval J \& Thieulant ML 1992 Multiple forms of affinity-labeled estrogen receptors in rat distinct pituitary cells. Endocrinology 131 1503-1510.

Gnessi L, Fabbri A \& Spera G 1997 Gonadal peptides as mediators of development and functional control of the testis: an integrated system with hormones and local environment. Endocrine Reviews 18 541-609.

Heldring N, Pike A, Andersson S, Matthews J, Cheng G, Hartman J, Tujague M, Strom A, Treuter E, Warner M et al. 2007 Estrogen receptors: how do they signal and what are their targets. Physiological Reviews 87 905-913.

Janulis L, Bahr JM, Hess RA \& Bunick D 1996 P450 aromatase messenger ribonucleic acid expression in male rat germ cells: detection by reverse transcription-polymerase chain reaction amplification. Journal of Andrology 17 651-658.

Johnston DS, Wright WW, DiCandeloro P, Wilson E, Kopf GS \& Jelinsky Scott A 2008 Stage-specific gene expression is a fundamental characteristic of rat spermatogenic cells and Sertoli cells. PNAS 105 8315-8320.

Jones ME, Boon WC, Poietto J \& Simpson ER 2006 Of mice and men: the evolving phenotype of aromatase deficiency. Trends in Endocrinology and Metabolism 17 55-64.

Joseph A, Shur BD, Ko CM, Chambon P \& Hess RA 2010 Epididymal hypo-osmolality induces abnormal sperm morphology and function in the estrogen receptor alpha knockout mouse. Biology of Reproduction 82 958-967.

Kimmins S, Kotaja N, Davidson I \& Sassone-Corsi P 2004 Testis-specific transcription mechanisms promoting germ-cell differentiation. Reproduction 128 5-12.

Klinefelter GR, Hall PF \& Ewing LL 1987 Effect of luteinizing hormone deprivation in situ on steroidogenesis of rat Leydig cells purified by a multistep procedure. Biology of Reproduction 36 769-783.

Krege JH, Hodgin JB, Couse JF, Enmark E, Warner M, Mahler JF, Sar M, Korach KS, Gustafsson JA \& Smithies O 1998 Generation and reproduction phenotype of mice lacking estrogen receptor beta. PNAS 95 15677-15682.

Leblond CP \& Clermont Y 1952 Definition of the stages of the cycle of the seminiferous epithelium in the rat. Annals of the New York Academy of Sciences $\mathbf{5 5}$ 548-573.

Levallet J \& Carreau S 1997 In vitro gene expression of aromatase in rat testicular cells. Comptes Rendus de l'Académie des Sciences III 320 123-129.
Levallet J, Bilinska B, Mittre H, Genissel C, Fresnel J \& Carreau S 1998 a Expression and immunolocalization of functional cytochrome $\mathrm{P} 450$ aromatase in mature rat testicular cells. Biology of Reproduction $\mathbf{5 8}$ 919-926.

Levallet J, Mittre H, Delarue B \& Carreau S $1998 b$ Alternative splicing events in the coding region of the cytochrome $\mathrm{P} 450$ aromatase gene in male rat germ cells. Journal of Molecular Endocrinology 20 305-312.

Li X \& Rahman N 2008 Impact of androgen/estrogen ratio: lessons from the aromatase over-expression mice. General and Comparative Endocrinology 159 1-9.

Lucas TF, Siu ER, Esteves CA, Monteiro HP, Oliveira CA, Porto CS \& Lazari MF 2008 17beta-estradiol induces the translocation of the estrogen receptors ESR1 and ESR2 to the cell membrane, MAPK3/1 phosphorylation and proliferation of cultured immature rat Sertoli cells. Biology of Reproduction 78 101-114.

Maruyama K, Endoh H, Sasaki-Iwaoka H, Kanou H, Shimaya E, Hashimoto S, Kato S \& Kawashima H 1998 A novel isoform of rat estrogen receptor beta with 18 amino acid insertion in the ligand binding domain as a putative dominant negative regulator of estrogen action. Biochemical and Biophysical Research Communications 246 142-147.

McLachlan RI, O’Donnell L, Meachem SJ, Stanton PG, de Kretser DM, Pratis K \& Robertson DM 2002 Identification of specific sites of hormonal regulation in spermatogenesis in rats, monkeys, and man. Recent Progress in Hormone Research 57 149-179.

Mowa CN \& Iwagana T 2001 Expression of estrogen receptor-alpha and -beta mRNAs in the male reproductive system of the rat as revealed by in situ hybridization. Journal of Molecular Endocrinology $\mathbf{2 6}$ $165-174$.

O'Donnell L, Robertson KM, Jones ME \& Simpson ER 2001 Estrogen and spermatogenesis. Endocrine Reviews 22 289-318.

Papadopoulos V, Carreau S \& Drosdowsky MA 1985 Effect of phorbol ester and phospholipase C on LH-stimulated steroidogenesis in purified rat Leydig cells. FEBS Letters 188 312-316.

Parvinen M 1982 Regulation of the seminiferous epithelium. Endocrine Reviews 3 404-417.

Pelletier G, Labrie C \& Labrie F 2000 Localization of oestrogen receptor alpha, oestrogen receptor beta and androgen receptors in the rat reproductive organs. Journal of Endocrinology 165 359-370.

van Pelt AM, de Rooij DG, van der Burg B, van der Saag PT, Gustafsson JA \& Kuiper GG 1999 Ontogeny of estrogen receptor-beta expression in rat testis. Endocrinology 140 478-483.

Petersen DN, Tkalcevic GT, Koza-Taylor PH, Turi TG \& Brown TA 1998 Identification of estrogen receptor $\beta 2$, a functional variant of estrogen receptor $\beta$ expressed in normal rat tissues. Endocrinology 139 1082-1092.

Price RH Jr, Lorenzon N \& Handa RJ 2000 Differential expression of estrogen receptor beta splice variants in rat brain: identification and characterization of a novel variant missing exon 4. Molecular Brain Research 80 260-268.

Prossnitz ER, Arterburn JB \& Sklar LA 2007 GPR30: a G proteincoupled receptor for estrogens. Molecular and Cellular Endocrinology 265-266 138-142.

Robertson KM, O'Donnell L, Jones ME, Meachem SJ, Boon WC, Fisher CR, Graves KH, McLachlan RI \& Simpson ER 1999 Impairment of spermatogenesis in mice lacking a functional aromatase (cyp19) gene. PNAS 96 7986-7991.

Saunders PTK, Maguire SM, Gaughan J \& Millar MR 1997 Expression of estrogen receptor beta (ER $\beta)$ in multiple rat tissues visualized by immunohistochemistry. Journal of Endocrinology 154 R13-R16.

Saunders PTK, Fisher JS, Sharpe RM \& Millar MR 1998 Expression of estrogen receptor beta (ER beta) occurs in multiple cell types, including some germ cells, in the rat testis. Journal of Endocrinology 156 13-17. 
Schaussi D, Tiffoche C \& Thieulant ML 2003 Regulation of the intronic promoter of rat estrogen receptor alpha gene, responsible for truncated estrogen receptor product-1 expression. Endocrinology $1442845-2855$

Sethumadhavan K, Bellino FL \& Thotakura NR 1991 Estrogen synthetase (aromatase). The cytochrome P-450 component of the human placental enzyme is a glycoprotein. Molecular and Cellular Endocrinology 78 25-32.

Shugrue PJ, Lane MV, Scrimo PJ \& Merchenthaler I 1998 Comparative distribution of estrogen receptor-alpha (ER-alpha) and beta (ER-beta) mRNA in the rat pituitary, gonad, and reproductive tract. Steroids 63 498-504.

Shupnik MA 2002 Oestrogen receptors, receptor variants and oestrogen actions in the hypothalamic-pituitary axis. Journal of Neuroendocrinology 14 85-94.

Silandre D, Delalande C, Durand P \& Carreau S 2007 Three promoters PII, PI.f and PI.tr direct the expression of aromatase (cyp19) gene in male rat germ cells. Journal of Molecular Endocrinology 39 169-181.

Sirianni R, Chimento A, Ruggiero C, De Luca A, Lappano R, Ando S, Maggiolini M \& Pezzi V 2008 The novel estrogen receptor, G protein-coupled receptor 30 , mediates the proliferative effects induced by 17 beta-estradiol on mouse spermatogonial GC-1 cell line. Endocrinology 149 5043-5051.
Skipper JK, Young LJ, Bergeron JM, Telzlaff MT, Osborn CT \& Crews D 1993 Identification of an isoform of the estrogen receptor messenger RNA lacking exon four and present in the brain. PNAS 90 7172-7175.

Tena-Sempere M, Barreiro ML, Gonzalez LC, Gaytan F, Zhang FP, Caminos JE, Pinilla L, Casanueva FF, Dieguez C \& Aguilar E 2002 Novel expression and functional role of ghrelin in rat testis. Endocrinology 143 717-725.

Tirado OM, Selva DM, Toran N, Suarez-Quian CA, Jansen M, McDonnell DP, Reventos J \& Munell F 2004 Increased expression of estrogen receptor beta in pachytene spermatocytes after short-term methoxyacetic acid administration. Journal of Andrology 25 84-94.

Toppari J \& Parvinen M 1985 In vitro differentiation of rat seminiferous tubular segments from defined stages of the epithelial cycle morphologic and immunolocalization analysis. Journal of Andrology 6 334-343.

Wing TY \& Christensen AK 1982 Morphometric studies on rat seminiferous tubules. American Journal of Anatomy 65 13-25.

Received in final form 25 May 2010

Accepted 15 June 2010

Made available online as an Accepted Preprint 16 June 2010 